\title{
The Effect of STEAM-Robotics on Science Subjects on Students' Ability to Solve Problems
}

Rochmatul Khikmiyah ${ }^{1}$, Rusijono ${ }^{2}$, Fajar Arianto 3

DOI: $10.35445 /$ alishlah.v13i3.694

\begin{tabular}{l}
\hline Article Info \\
\hline Keywords : \\
Problem-solving ability, \\
STEAM-Robotics, \\
Approach, \\
Science Subjects
\end{tabular}

Kata Kunci:

Kemampuan pemecahan masalah, STEAM-Robotics, Pendekatan, $I P A$

\section{Abstract}

The development of the industrial and social revolutions today demands an increase in the quality of human resources who appear as intelligent humans and are able to solve problems. This study aims to determine the effect of the STEAM-Robotics approach in science learning on students' ability to solve problems. So it is hoped that STEAM-Robotics can make students find innovative solutions to real problems and convey them well. This study used an experimental research design, pretest-posttest control group design with one type of treatment. Methods of data collection are done using observation and performance tests. This research was conducted on 81 grade VII students with two T-test analyses, namely the pretest and post-test results of the experimental and control groups. The results showed that the STEAM-Robotics approach in science subjects affected students' problem-solving ability.

\section{Abstrak}

Perkembangan revolusi industri dan sosial saat ini menuntut peningkatan kualitas sumber daya manusia yang tampil sebagai manusia yang cerdas dan mampu memecahkan masalah. Penelitian ini bertujuan untuk mengetahui pengaruh pendekatan STEAM-Robotics dalam pembelajaran IPA terhadap kemampuan siswa dalam memecahkan masalah. Sehingga diharapkan STEAMRobotics dapat menjadikan mahasiswa mampu menemukan solusi inovatif terhadap permasalahan nyata dan dapat menyampaikannya dengan baik. Penelitian ini menggunakan desain penelitian eksperimen yaitu pretest posttest control group design dengan satu jenis perlakuan. Metode pengumpulan data dilakukan dengan cara observasi dan tes unjuk kerja. Penelitian ini dilakukan pada 81 siswa kelas VII dengan dua analisis uji-T, yaitu hasil pretest dan posttest kelompok eksperimen dan kontrol. Hasil penelitian menunjukkan bahwa pendekatan STEAM-Robotics pada mata pelajaran IPA berpengaruh terhadap kemampuan siswa dalam memecahkan masalah.

\footnotetext{
${ }^{1}$ Universitas Negeri Surabaya, Surabaya, Indonesia

Email: rochmatul.19013@mhs.unesa.ac.id

${ }^{2}$ Universitas Negeri Surabaya, Surabaya, Indonesia

Email: rusijono@unesa.ac.id

3 Universitas Negeri Surabaya, Surabaya, Indonesia

Email: fajararianto@unesa.ac.id
} 


\section{INTRODUCTION}

The training process for Industry 4.0 is a global priority, as the rate of technological advancement is several times faster than the rate of change in the educational system. Many of the jobs taught today will become obsolete in the future, necessitating the development of a new educational model that is responsive to the changing industrial production paradigm. The World Economic Forum (2016) identifies problem-solving as one of the skills necessary for the 21st-century workplace. Critical thinking and problem-solving abilities are prerequisites for confronting complex challenges. STEM-based education develops Human Resources (HR) capable of reasoning and thinking critically, logically, and systematically, preparing them to compete on a global scale and lifting the country's economy (Asmuniv, 2015).

Science or natural science (IPA) is a subfield of a scientific discipline that exemplifies scientific behavior and significantly impacts our ability to solve problems. This is consistent with junior high school science instruction objectives, which include students demonstrating scientific behavior in daily activities, such as being curious, objective, thorough, honest, responsible, diligent, open, critical thinking, innovative, creative, and environmentally conscious. The development of intelligence or intelligence that a person has to use to their advantage in their lives both now and in the future is the primary goal of education in today's 21st century. This necessitates the development of skills that can maximize its potential. According to Murwianto and Sentot (2017), students need to be prepared for the challenges of the 21st century by learning science in a way that improves their ability to think critically. Teachers, particularly those in the sciences, are expected to play an active role in preparing students for the 21st century by studying science, technology, engineering, and mathematics (STEM) (Han, Yalvac, Capraro, MM, and Capraro, RM, 2014). Students should not only be able to solve simple problems on their own, but they should also be able to solve more complex ones so that it is not enough to see a problem from a single perspective but rather from a variety of perspectives. The 4 Cs, i.e., creativity, critical thinking, collaboration, and communication, are incorporated into STEM learning activities to help students develop creative solutions to real-world problems and effectively communicate those solutions to others (Beers, 2011). Students' ability to solve problems is based on thinking critically. Learning in the 21st century requires students to have the following four skills.

According to the findings of various studies, STEM and robotics education foster problemsolving abilities. Based on their research into the impact of STEM education and robotics learning on students' performance in exercises, problem-solving, and projects, Barak \& Assal (2016) conclude that STEM education benefits greatly from incorporating robotics. Students' interest in STEM subjects increases when they are exposed to robotics education, according to Khanlari's (2013) research on the impact of robotics education on STEM learning and students' attitudes toward STEM. The robotics-based STEAM education program (robot soccer) developed and implemented by Baek \& Yoon (2016) aims to develop an integrated STEAM program that considers activities and interests in 6th-grade science subjects to identify their influence on the creativity and interest levels of elementary school students. According to the findings, students' ability to think creatively and their enthusiasm for science increased significantly.

Several studies conducted over the last five years indicate that this study is unique in that it examines the STEAM-Robotics approach in science subjects for class VII and its effect on students' ability to solve problems. The application of STEAM-Robotics through project-based learning with low-cost tools and materials can even make use of repurposed items from the surrounding environment. This project can be completed independently by adopting the theme of a simple robotics project and focusing on adaptation to current pandemic conditions. This is in contrast to previous studies, which employed more expensive electronics-based robot kits. At the secondary level (SMP), the embedded STEM approach may be more feasible (Roberts, 2012). Several studies conducted over the last five years indicate that this study is unique in that it examines the STEAMRobotics approach in science subjects for class VII and its effect on students' ability to solve 
problems. The application of STEAM-Robotics through project-based learning with low-cost tools and materials can even make use of repurposed items from the surrounding environment. This project can be completed independently by adopting the theme of a simple robotics project and focusing on adaptation to current pandemic conditions. This is in contrast to previous studies, which employed more expensive electronics-based robot kits. At the secondary level (SMP), the embedded STEM approach may be more feasible (Roberts, 2012).

STEM education, founded on problem-solving, discovery, and exploratory learning, seeks to refocus the classroom's attention away from the teacher and the students (Fioriello, 2020). Students learn how to apply the STEAM approach to their school projects through a project-based learning model (PjBL). Sanders (2009) asserts that students require a project-based integrated technology education program to assist them in resolving real-world technology and engineering problems. STEAM is a method that integrates science, technology, engineering, art, and mathematics in both the education and learning process centred on solving everyday and professional problems. In the opinion of Baek \& Yoon (2016) stated that STEAM education can foster the conversion of thinking and problem solving based on science and technology. With the integration of science, technology, engineering, art and mathematics, the STEAM approach can help students solve problems and capture conclusions from previous learning (Robert \& Cantu, 2012; Lou et al., 2017). This result is supported by previous findings by Kim, Ko, Han, and Hong (2014) that STEAM education affects increasing academic achievement, creative problem-solving abilities, and scientific attitudes.

According to Shengquan and $\mathrm{Hu}$ Xiang (2015), the integrated core characteristics of STEM education are the following: interdisciplinary, engaging, experiential, situational, collaborative, design, artistic, empirical, and technical enhancement. These characteristics are also reflected in how robots are educated. Robotic education is a vehicle for high-quality education that spans a broad range of disciplines and sits at the nexus of science, technology, engineering, mathematics, and the arts. It eliminates divisions between disciplines and places a premium on integrating interdisciplinary content. Robotics classes are designed around students' interests and cognitive and behavioural rules.

Researchers and educators have used robots to aid in education since the development of robotic technology. They outlined the numerous advantages of incorporating robotics into the classroom. According to Khanlari (2013)'s research, robotics aids students in learning STEM subjects. The results indicated that robotics piqued students' interest in STEM subjects. This discovery exemplifies the theory of Constructivism and Constructionism in a novel way. This research is critical because several research findings demonstrate the value of project-based learning that integrates multiple disciplines, including robotics, and can help students improve their problem-solving skills. To adapt to current pandemic conditions, the STEAM-Robotics learning process can be conducted online.

\section{METHOD}

This study used an experimental research design, namely pretest-posttest control group design with one type of treatment. The research was conducted by engineering a condition that was then observed regarding the effects caused by the treatment or engineering. Experimental research used 2 groups that were compared, namely the experimental group with treatment and the control group without treatment. The experimental and control groups have the same or nearly the same (homogeneous) characteristics and properties. The experimental group received treatment in the form of science learning using the STEAM-Robotics approach and then observed the application of this approach. The pretest was given before the treatment for the two groups which was then analyzed to see the initial conditions in both groups. In contrast, the post-test is given after the treatment and at the end of the lesson. The effectiveness of the treatment is indicated by the difference between the results of the post-test in the experimental and control groups. 
This research was set in Al Uswah Integrated Islamic First Secondary School Surabaya. And during the implementation of the research from March to May 2021. Meanwhile, the research subjects used were seventh-grade students of SMP-IT Al Uswah Surabaya, with 107 students. The experimental class numbered 52 students, and the control class numbered 55 students. Methods of data collection are done using observation and performance tests. (1) Observation is used to collect data on the independent variable (X1), namely the application of STEAM-Robotics. Observations were made to see how the suitability of the application of STEAM-Robotics with the project-based learning model taking place in the classroom to the learning design that had been made.

In testing the hypothesis, T-test analysis was carried out twice. The first analysis was to analyze the pretest results to measure students' learning motivation and initial ability to solve problems in the comparison group and the experimental group (O1 : O2 ). If the initial results are the same, then the second t-test is carried out on the post-test data. Still, if the initial results (O1 : O2 ) are different, the second t-test is carried out on the difference between the pretest-posttest of the two groups ( $\mathrm{O}_{3}$

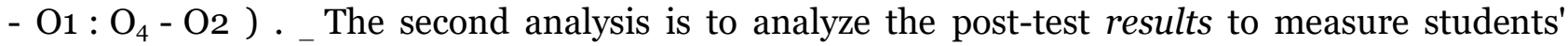
motivation and final ability to solve problems in the experimental group and the control group $\left(\mathrm{O}_{3}\right.$ : $\left.\mathrm{O}_{4}\right)$. If there is no difference between $\mathrm{O}_{1}$ and $\mathrm{O}_{2}$ and there is a difference between $\mathrm{O}_{3}$ and $\mathrm{O}_{4}\left(\mathrm{O}_{3}\right.$ is greater than $\mathrm{O}_{4}$ ) or if there is a difference between $\mathrm{O}_{1}$ and $\mathrm{O}_{2}$. There is a difference between $\mathrm{O}_{3}-\mathrm{O}_{1}$ and $\mathrm{O}_{4}-\mathrm{O}_{2}\left(\mathrm{O}_{3}-\mathrm{O}_{1}\right.$ is greater than $\left.\mathrm{O}_{4}-\mathrm{O}_{2}\right)$ it can be concluded that the STEAM-Robotics approach has a positive effect on motivation and problem-solving ability.

\section{FINDINGS AND DISCUSSION}

Variable data of the STEAM-Robotics approach was obtained from observations by the observer by filling out the checklist sheet for implementing the STEAM-Robotics approach on a Guttman scale. Then the percentage calculation is carried out to determine whether the classification of learning activities is included in the very good, good, sufficient or less categories. The formula used is the total score obtained divided by the maximum score multiplied by 100 (value $=$ total score obtained / maximum score x 100). Thus obtained a score of 89.2 with a very good category, meaning that the process of implementing the STEAM-Robotics approach has been carried out well according to the project-based learning model procedure. The STEAM-Robotics approach that has been carried out is by natural science material related to potential energy and kinetic energy. Students are shown an example of a STEAM - Robotics project and then explained the implementation of the energy materials contained in the project. The STEAM-Robotics approach is carried out with the following details: 

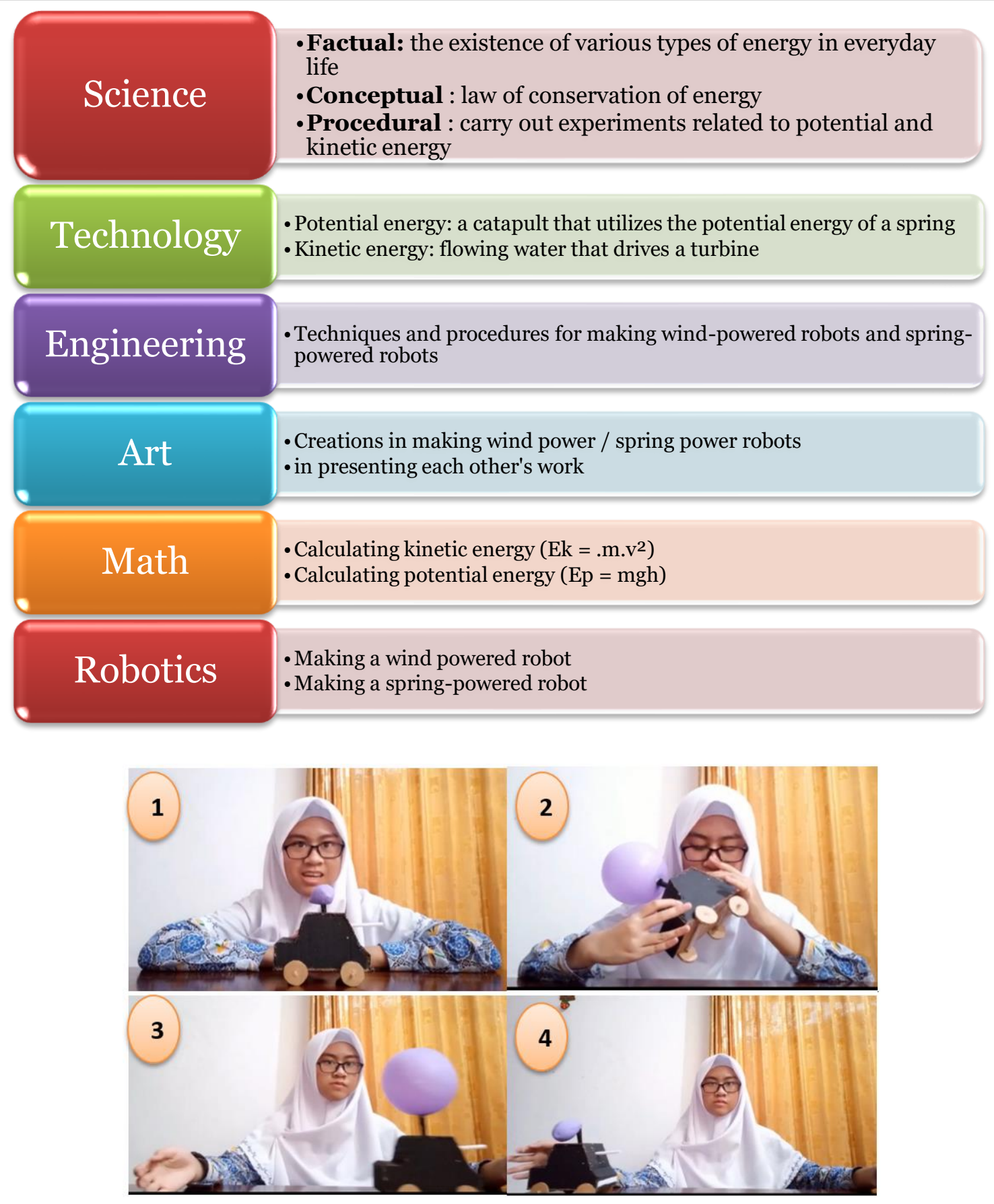

Figure 1. Results of the STEAM-Robotics project

Students' problem-solving abilities were measured using the results of their pre-and post-tests, which yielded percentage and average values that could be used to determine a student's level of proficiency. As a result, the control class had an average value of 58,875 , and the experimental class had 62.1. This graph shows that both the control and experimental groups' total problem-solving abilities fall within the sufficient range. The average difference between the experimental and control groups' scores is 3.23 points. Before an independent t-test can be performed, the average difference cannot be used as a reference for differences in students' problem-solving abilities. Results from the pretest for problem-solving ability showed that the two groups had different starting points. It was then determined that the difference in data between the experimental and control groups was significant enough to warrant the use of a T-test.

Before testing the hypothesis, it is necessary to test the analysis prerequisites, namely the normality test and homogeneity test assisted by the data processing program, namely SPSS version 
22 (Statistical Product and Service Solution). The normality test uses the Shapiro Wilk test because random data distributions are not more than 50 samples. This test has criteria if the significance value or probability value is less than 0.05 , then the distribution is considered abnormal and vice versa. Based on the results of table 3, it can be seen that the normality test with Shapiro-Wilk shows a significant value (Sig) greater than 0.05. So it can be concluded that the data from both groups are normally distributed. The following are the details of the results of the normality test for the difference between the pretest-posttest data on the ability to solve problems:

Table 1. Normality Test Results

\begin{tabular}{|ll|r|r|r|r|r|r|}
\hline \multirow{2}{*}{} & \multicolumn{4}{|c|}{ Kolmogorov-Smirnov a } & \multicolumn{4}{|c|}{ Shapiro-Wilk } \\
\cline { 3 - 9 } GROUP & & Statistics & \multicolumn{1}{|c|}{ df } & \multicolumn{1}{c|}{ Sig. } & Statistics & \multicolumn{1}{c|}{ df } & \multicolumn{1}{c|}{ Sig. } \\
\hline $\begin{array}{l}\text { PROBLEM } \\
\text { SOLVING }\end{array}$ & $\begin{array}{l}\text { CONTROL } \\
\text { CLASS } \\
\end{array}$ &, 141 & 32 &, 105 &, 934 & 32 & 0.051 \\
& $\begin{array}{l}\text { EXPERIMENT } \\
\text { CLASS }\end{array}$ &, 145 & 16 &, $200 *$ &, 929 & 16 &, 234 \\
\hline
\end{tabular}

*. This is a lower bound of the true significance.

a. Lilliefors Significance Correction

The homogeneity test is generally used as a requirement in the mean difference test, such as the ANOVA test, the Mann Whitney test, and the independent t-test. In the independent t-test, the homogeneity test is not an absolute requirement. Because of the variance between these groups is homogeneous, it will be able to produce accurate measurements in the difference test. In table 4, the homogeneity test results can be seen that the value of Sig. greater than 0.05 , it can be concluded that the data on the difference between the pretest-posttest ability to solve problems in the two groups is homogeneous (same).

Table 2. Homogeneity Test Results

\begin{tabular}{|ll|r|r|r|r|}
\hline & $\begin{array}{c}\text { Levene } \\
\text { Statistics }\end{array}$ & \multicolumn{1}{c|}{ df1 } & \multicolumn{1}{c|}{ df2 } & \multicolumn{1}{c|}{ Sig. } \\
\hline PROBLEM & Based on Mean &, 463 & 1 & 46 &, 500 \\
SOLVING & Based on Median &, 302 & 1 & 46 &, 586 \\
& $\begin{array}{l}\text { Based on Median and } \\
\text { with adjusted df } \\
\text { Based on trimmed } \\
\text { mean }\end{array}$ &, 302 & 1 & 43,192 &, 586 \\
&, 514 & 1 & 46 &, 477 \\
\hline
\end{tabular}

The hypothesis test used is the independent t-test on the difference in the pretest-posttest value of the experimental group and the control group with the Independent Sample T-Test (Test) test formula assisted by the SPSS version 22 program. The alternative hypothesis (Ha) is that there is an effect of the STEAM-Robotics approach on science subjects on students' problem-solving abilities, while the null hypothesis (Ho) is that there is no effect of the STEAM-Robotics approach on science subjects on students' problem-solving abilities. Decision making is based on the significance value (2-tailed). If the value of Sig. (2-tailed) is greater than 0.05, then the conclusion is Ho is accepted, Ha is rejected otherwise if the value of Sig. (2-tailed) is less than 0.05, then the conclusion is Ho is rejected, Ha is accepted. The results of the independent t-test can be seen with the following details: 
Tabel 3. Hasil Uji Independent T Test

\begin{tabular}{|c|c|c|c|c|c|c|c|c|c|c|}
\hline & \multicolumn{2}{|c|}{$\begin{array}{c}\text { Levene's Test } \\
\text { for Equality of } \\
\text { Variances }\end{array}$} & \multicolumn{7}{|c|}{ t-test for Equality of Means } \\
\hline & & \multirow[b]{2}{*}{$\mathrm{F}$} & \multirow[b]{2}{*}{ Sig. } & \multirow[b]{2}{*}{$\mathrm{t}$} & \multirow[b]{2}{*}{ df } & \multirow{2}{*}{$\begin{array}{l}\text { Sig. } \\
(2- \\
\text { tailed } \\
\quad)\end{array}$} & \multirow{2}{*}{$\begin{array}{c}\text { Mean } \\
\text { Differenc } \\
\text { e }\end{array}$} & \multirow{2}{*}{$\begin{array}{l}\text { Std. } \\
\text { Error } \\
\text { Differe } \\
\text { nce }\end{array}$} & \multicolumn{2}{|c|}{$\begin{array}{l}\text { 95\% Confidence } \\
\text { Interval of the } \\
\text { Difference }\end{array}$} \\
\hline & & & & & & & & & Lower & Upper \\
\hline $\begin{array}{l}\text { PROBLEM } \\
\text { SOLVING }\end{array}$ & $\begin{array}{l}\text { Equal } \\
\text { variances } \\
\text { assumed } \\
\text { Equal } \\
\text { variances } \\
\text { not } \\
\text { assumed }\end{array}$ & ,463 &, 500 & $\begin{array}{r}-7,781 \\
- \\
7,356\end{array}$ & $\begin{array}{r}26, \\
070\end{array}$ & , OOO & $-14,0469$ & 1,8054 & $-17,6809$ & $-10,4129$ \\
\hline
\end{tabular}

The test results above show the value of Sig. (2-tailed) of 0.000 on equal variances assumed so that it can be concluded that Ho is rejected and Ha is accepted, which means that there is an effect of the STEAM-Robotics approach on science subjects on the ability to solve problems for class VII students at SMP-IT Al Uswah Surabaya. This is by the opinion of Baek \& Yoon (2016), which states that STEAM education can foster the conversion of thinking and problem solving based on science and technology. This result is supported by previous findings by Kim, Ko, Han, and Hong (2014) that STEAM education affects increasing academic achievement, creative problem-solving abilities, and scientific attitudes. STEM education is used to address real-world situations through a design-based problem-solving process, as used by engineers or scientists (Williams, 2011). In addition, there is significant evidence from the use of the STEM approach, namely that the level of mastery of science and mathematics can exceed predetermined standards (Amri et al., 2020). Embedded STEM-based science learning can be the beginning to start developing STEM education at SMP N 1 Masaran while still following the national curriculum (2013 curriculum) without restructuring (Firman, 2015).

STEAM is generally conceptualized as a transdisciplinary teaching and learning approach (Guyotte et al., 2015). Transdisciplinary refers to a method in which the problem to be solved comes first, with the discipline emerging naturally from the questions asked. STEAM instruction has been conceptualized as (1) using problem-based learning; (2) using technology; (3) allowing multiple lines of inquiry to solve problems; (4) considering science, technology, engineering, arts/humanities and mathematics and; (5) utilize collaborative problem solving (Herro \& Quigley, 2017). STEM education involves students in metacognitive activities. The implementation of STEM education in the classroom allows students to understand the importance of integrating various disciplines and their applications. Students can improve their logical thinking through it all (Anwari et al., 2015).

Project-based learning is a learning model that is applied to implement the STEAM-Robotics approach. Basically, this project-based learning model is a learning model that starts from the existence of a problem and then students are invited to be able to solve the problem. In the problemsolving process, students are invited to think critically so that they can improve their cognitive skills. This robotics project-based approach to STEAM-Robotics has a positive effect on problem-solving skills. This is supported by the results of research by Barak \& Assal (2016), which states that robotics in the STEAM approach is useful for developing broad learning skills such as scientific inquiry, engineering design, problem-solving, creative thinking and teamwork. Successful experience includes the ability to resolve conflicts through creative problem-solving approaches and project accomplishments that make them more aware of real-life problems and issues. Therefore, PjBL plays 
an important role in exposing students to meaningful learning processes when they complete their projects (Musa, Mufti, Latiff, et al., 2011).

The relationship between the STEAM-Robotics approach and the ability to solve this problem can also be seen from the theory. The theory that underlies the STEAM-Robotics approach is the theory of constructionism. This theory refers to constructivism and emphasizes the hand aspect. Constructionism emphasizes that building real and meaningful objects, finding problems, and solving them are the most efficient ways of learning. The goal of constructionism is to give children good things to do to learn by doing much better than before (Papert, 1980). Students who can make their own robotics projects can provide a stimulus to do new challenging things. Integrated STEM education raises more questions than it currently answers (English, 2016). When students are more trained to do their own projects, it will be easier for them to find solutions to every problem they face. Integrating several disciplines in the STEAM-Robotics approach is often encountered in everyday life. Students can solve new problems and draw conclusions based on previously learned principles applied through science, technology, engineering, and mathematics (Roberts, 2012).

The results of this study are also supported by several previous studies from Anindya \& Wusqo's (2020) research regarding the effect of PjBL-STEAM on students' problem-solving skills, which show that there are differences in the average of the three problem-solving skills indicators with several advantages which include (1) training students in thinking about the steps or stages they will take to solve a problem, (2) creating products that contain elements of science and technology, engineering, art, and mathematics so that learning becomes interesting and fun while stimulating creativity and (3) improving oral and written communication skills. Student writing. In line with that, Ridwan et al. (2018)'s research revealed that STEAM with project-based learning could develop students ' soft skills. One of the soft skills studied is critical thinking which is the cognitive basis needed by students in solving a problem. STEM can mean increasing technical recognition in K-12 education, including the junior high school level (Bybee, 2010). The development of STEM literacy in Indonesia is very much needed, although it is not an easy matter. It takes at least a decade to develop STEM education (Bybee, 2010; Firman, 2015). The " embedded STEM " form is more appropriate at the high school level. This is possible without restructuring the curriculum of junior high schools in Indonesia. This integration incorporates technology, engineering, and mathematics content in STEM-based science learning (Firman, 2015).

Robotics integrated with STEAM helps teachers in teaching science or science learning. This is supported by research by Susilo (2016), who argues that simple robots being used in STEM education are powerful tools that facilitate teaching STEM knowledge. In addition, Robotics also provides an interesting way to turn a boring concept into a fun learning process. Robot kits facilitate the ease with which students can make connections between STEM disciplines. The project-based learning model used in the STEAM-Robotics approach is very helpful for students in understanding the concept of material in the learning objectives. This is in line with Herro \& Quigley's (2017) research on STEAM integration which was explored through project-based learning. His research shows that STEAM is an effective first step to change practice because of the importance of collaboration and technology that is directly integrated into the learning process.

\section{CONCLUSION}

The STEAM-Robotics approach in science learning positively affects students' ability to solve problems. This is based on the results of the independent t-test analysis. There is a significant difference between the pretest-posttest difference in the control and experimental groups with sig values. of 0.000 (Sig. value < 0.05). The STEAM-Robotics approach is devoted to using a projectbased learning model that requires students to produce a product. The teacher monitors and guides students in the project work process. Suppose the STEAM-Robotics approach is to be used in other schools. In that case, it is necessary to analyze the needs of these schools, especially in terms of 
student characteristics, teacher characteristics, school characteristics, or school-owned facilities.

The STEAM-Robotics approach needs to be applied to improve students' ability to solve problems, especially in science subjects, because the subject matter is by the STEAM-Robotics approach, namely science, technology, engineering, art, mathematics and robotics. Before applying this approach, it is better to conduct a needs analysis to find problems and be able to determine appropriate teaching materials as a solution to solving these problems.

\section{REFERENCES}

Amri S M., Sudjimat A D., Nurhadi Didik. 2020. Combining Project-Based Learning with STEM to Improve Technical Learning Outcomes and Work Character of Vocational High School Students . Journal of Technology, Vocational and Teaching Vol. 43, No. 1, February 2020: 4150. DOI: http://dx.doi.org/10.17977/um031v43i12020p41-50

Anwari, I., et al. 2005. Implementation of Authentic Learning and Assessment through STEM Education Approach to Improve Students' Metacognitive Skills . K-12 STEM Education, 1(3), p.123-136. DOI: 10.14456/k12stemed.2015.24

Apriliana R.M., Ridwan A., Rahmawati Y., Hadinugrahaningsih T. 2018. Development of Learner Soft Skills through Integration of Science, Technology, Engineering, Arts, and Mathematics (STEAM) Approaches in Acid-Base Learning . Journal of Chemical Education Research 2018 Vol.8 No.2 . DOI: https://doi.org/10.21009/JRPK.082.05

Asmuniv. 2015. Integrated Approach to STEM Education Efforts to prepare Indonesian Human Resources with Interdisciplinary Knowledge to Meet the Career Needs of the ASEAN Economic Community (MEA). Retrieved from: http://www.vedcmalang.com/pppptkboemlg/index.php/menuutama/listrik-electro/1507asv9.

Baek, J.-E., \& Yoon, M.-B. 2016. Development and Application of STEAM Education Program Based on Robots: Through a Theme Based Robot Soccer . International Journal of Computer Science and Information Technology for Education, 1(1), 27-34 . DOI: 10.4018/IJMBL.2018070102

Barak, Moshe \& Assal, M., 2016. Robotics and STEM learning: students' achievements in assignments according to the P3 Task Taxonomy-practice, problem solving, and projects. Int J Technol Des Educ (2018) 28:121-144. DOI : 10.1007/s10798-016-9385-9

Beers, S.Z. 2011. 21st Century Skills: Preparing for Their Future. London : ASD Author. Microsoft Word - 21stCenturySkills.doc (umaine.edu)

Bybee, R. W. 2010. Advancing STEM Education: A 2020 Vision. Technology and Engineering Teacher, 70(1), p.30-35. https://doi.org/10.1119/1.2343473

English, L.D. (2016). STEM Education K-12: Perspectives on Integration. International Journal of STEM Education, 3 (3), p.1-8. DOI 10.1186/s40594-016-0036-1.

Firman, H. 2015 . STEM-Based Science Education: Concepts, Development, and Role of Postgraduate Research . Proceedings of the National Seminar on Science and PKLH Education. Pakuan University Postgraduate Program, Bogor

Guyotte, KW, Sochacka, NW, Costantino, TE, Kellam, N., Kellam, NN, \& Walther, J. 2015. Collaborative creativity in STEAM: Narratives of art education students' experiences in transdisciplinary spaces . International Journal of Education \& the Arts, 16(15), 1-39. Retrieved from http://www.ijea.org/v16n15/

Han, S., Yalvac, B., Capraro, M.M., \& Capraro, R.M. 2015. In-service Teachers' Implementation and Understanding of STEM Project Based Learning. Eurasia Journal of Mathematics, Science \& Technology Education, 11(1), p.63-7. DOI: 10.12973/eurasia.2015.1306a

Herro, D., \& Quigley, C. 2017. Exploring teacher perceptions of STEAM: Implications for practice. Professional Development in Education, 43, 416-438. DOI:10.1080/19415257.2016.1205507 
Khanlari, Ahmad. 2013. Effects of Educational Robots on Learning STEM and on Students' Attitude Toward STEM. 2013 IEEE 5th Conference on Engineering Education (ICEED). DOI: 10.1109/ICEED.2013.6908304

Kim, D. H., Ko, D. G., Han, M. J., \& Hong, S. H. 2014. The Effects of science lessons applying STEAM education program on the creativity and interest levels of elementary students. Journal of the Korean Association for Science Education, 34(1), 43-54. DOI:10.14697/JKASE.2014.34.1.1.00043

Lou, Shi-Jer, Yung-Chieh Chou, Ru-Chu Shih, \& Chih-Chao Chung. 2017. A Study of Creativity in CaC2 Steamship-derived STEM Project based Learning. EURASIA Journal of Mathematics $\begin{array}{lllll}\text { Science and Technology } & 2404 .\end{array}$ https://doi.org/10.12973/eurasia.2017.01231a

Lucas, George. 2005. Instructional Module Project Based Learning . http://www.edutopia.org.modules/PBL/whatpbl.php. Source:http://www.eureka Pendidikan.com/2014/12/model-project-based-learning-landasan.html

Murnawianto S., Sarwanto, \& Sentot BR 2017 . STEM-Based Learning in Junior High School: Potential for Training Students' Thinking Skills. Radiance of Education FKIP University of Jember 6 (4): 69-80. DOI:10.25037/pancaran.v6i4.86

Musa F., Mufti N., Latiff RA., et al. 2011. Project-based learning (PjBL): Inculcating soft skills in $21^{\text {st }}$ century workplace. Procedia-Social Behav Sci 2012; 59: 565- 573. Elsevier Ltd. Selection and/or peer reviewed under responsibility of the UKM Teaching and Learning Congress 2011. DOI: 10.1016/j.sbspro.2012.09.315.

Papert, Seymour. 1980. Constructionism vs. Instructionism. Available at http://www.papert.org/articles/const_inst/const_inst1.html

Roberts, A. \& D. Cantu. 2012. Applying Stem Instructional Strategies To Design And Technology Curriculum. Technology Education in the 21st Century, Proceeding of the PATT 26 Conference. Linkoping Uviversity, Stockholm. ecp12073013.pdf (liu.se)

Roberts, A. 2012. A Justification for STEM Education. Technology and Engineering Teacher, 74 (8), p.1-5. File.aspx (iteea.org)

Susilo et al. 2016. STORMLab for STEM Education: An Affordable Modular Robotic Kit for Integrated Science, Technology, Engineering, and Math Education. IEEE Robotics \& Automation Magazine, vol. 23, no. 2, pp. 47-55. https://doi.org/10.1109/MRA.2016.2546703

Williams, J. 2011. STEM education: Proceed with caution. Design and Technology Education, 16(1), 26-35

World Economic Forum. 2016. The Future of Jobs: Employment, Skills and Workforce Strategy for the Fourth Industrial Revolution. Global Challenge Insight Report. 